\title{
Russian Identities and the Idea of International Society 20 Years after the Fall of the USSR
}

\section{Andrey Makarychev}

\begin{abstract}
.
In the paper the author analyzes different Russian international identities of the post-Soviet period. Stressing that the Russian identity discourse cannot be simply reduced to the Soviet one, the paper emphasizes the plurality of Russia's identity discourses. At the same time the menu of Russian foreign policy identities to a large extent depends upon a variety of international structures in which Russia may imagine to engage with. The paper suggests that there are four possible types (models) of the international society, which different Russian identities might be inscribed in. The author seeks to explain the range of Russian international identities by the variety of the patterns of international society which co-exist and offer alternative policy strategies for Moscow.
\end{abstract}

\section{Introduction}

I will start my analysis with one preliminary observation: twenty years is a sufficient time span for assessing the efficacy of qualitative transitions from one regime of power to another. In 20 years frame some countries, having detached themselves from authoritarian rule, succeeded in drastically altering their policy priorities and achieved recognition by - and membership in - major institutions of international society. This is the case of Germany after the Second World War, Spain and Portugal after the fall of dictatorial regimes, and Baltic and Central European countries after the demise of the Berlin Wall.

Though the Russian authorities have claimed that the transitory period is over and Russia has restored its authenticity and "normalcy," this is, in my view, very far away from true. Russia in many regards is still at the cross-roads, facing multiple political choices and trying to manoeuvre between different pathways to its future. Some of these choices are heavily influenced by the century-long debates between Slavophiles and Westernizers, but there are other, more nuanced meanings imbued in the contemporary menu of Russian alternative futures. In this sense, the Russian discourses of self-description and self-presentation are doomed to remain dispersed and fragmented, with much lesser level of consolidation (or "sedimentation," in the vocabulary of the critical theory) around key unifying concepts.

The argument I am going to develop in this article suggests that the menu of Russian foreign policy identities to a large extent depends upon a variety of international structures in which Russia may imagine to engage with. I will start 
with explaining the drastic differences between today's Russia and the Soviet times. Drawing upon the idea of plurality of Russian discourses of national role identities, I will claim that each of them is an inter-subjective construct, and will illustrate this point by referring to the Russian - EU discursive relations. Then I will present and explain the concept of international society which has a rich theoretical legacy and practical significance for studying the gamut of alternative international identities and policy strategies of Russia.

\section{Identity Shifts: Why Russia Is Not the USSR}

In the Western discourses Russia under the Putin - Medvedev regime is often compared (or even equated) with the Soviet Union. This logic is grounded in the resilience of the old Soviet domestic practices and foreign policy ambitions in the area known as Russia's "near abroad." However, I base my analysis on a different approach which is consonant with Ted Hopf's distinction between the Soviet and Russian identity discourses. As seen from ( $t$ )his perspective, the Soviet identity was grounded in a number of key signifiers:

- the idea of "the new Soviet man," which makes ethnic or religious identities excessive, harmful and only tolerable as folkloric rituals;

- the concept of class struggle, hence the class-based foundation of the friends - foes distinction, and the view of the USSR as the vanguard of "progressive mankind" struggling against the "world capitalism";

- modernity as the reference point of the Communist strategy, hence greatpowerness as an effect of enforced modernization / industrialization;

- a-historicity, or a radical break with Russia's historical experience which was regarded as a burden rather than an important identity resource. ${ }^{1}$

Yet after 1991 this set of characteristics was radically altered. Unlike the overideologized Soviet Union, Russia has explicitly proclaimed itself "pragmatic" and de-politicized type of subject, guided by the desire to be recognized in the West as a "normal" European power. Instead of the unified identity promoted by the Soviet elite, Russia's identity narratives are referred to the multiplicity of Others - external (mostly United States, more rarely Europe, yet only seldom China), internal (from oligarchs to self-minded regional elites) and historical (whose list might include Stalin, Ivan the Terrible, etc., depending on political dispositions). Russia also experienced the renaissance of sub/trans-national

1 Ted Hopf, Social Construction of International Politics. Identities and Foreign Policies, Moscow 1955 and 1999 (Ithaca: Cornell University Press, 2001). 
(ethnic and religious) identities that previously were considered "obsolete" and "pre-modern."

Against this background, Russia may be dubbed a "post-empire," which makes it different from the Communist empire of the Soviet Union. However, it is exactly here where identity games start: in spite of Russia's longing for the role of a "normal European power," it is widely perceived in the West as a "neoempire" eager to use for expansionist purposes its energy resources and even military force. This perception gap is the constitutive element in the chain of Russian - European discursive disconnections which are perfectly visible in the divergent symbolizations of two key historical moments of the $20^{\text {th }}$ century by each of the parties. One of them is the Second World War, which is traditionally referred to in Russia as the Great Patriotic War. Russia and Europe not only use different names for it and different dates to celebrate its end (May 9 in Russia and May 8 in the West); the gaps between the two parties are much deeper than that. In Russia the May 9 symbolizes not only Russia's strength as a great power, but also its belongingness to the European political tradition void of any meaningful normative background (the acceptance of Stalin as a full-fledged partner of western democracies is a good illustration of the power politics argument). Yet in Europe the end of the Second World War is a combination of celebration and mourning, since for many East/Central European nations the liberation from the Nazi troops was followed by the occupation of their territories by the Red Army.

Another important historical turning point is the fall of the Soviet Union in 1991. References to 1991 are always part of political discourses; both in Europe and Russia, but the semantic meanings of these references are drastically different, which reveals stark normative cleavages between Russia and Europe. The fall of the USSR is deplored as the "largest geopolitical catastrophe of the $20^{\text {th }}$ century" by the Kremlin, and celebrated in the West as the key event of the relatively peaceful democratic revolution in the former Soviet bloc. For most Europeans, the dissolution of the USSR was not the major disaster of the $20^{\text {th }}$ century, especially against the backdrop of the experience of the two world wars, and the bloody ethnic cleansings in the Balkans. These comparisons demonstrate how deep the value gap between the official Russia and Europe is, which Russia seems to be unable and unwilling to bridge.

\section{Identities in Plural}

Yet Russia's identity is far from fixed. The dissolution of the USSR has unveiled a multiplicity of narratives that could make one think of Russia as a country dwelling in different epochs simultaneously. ${ }^{2}$ In Russia, indeed, despite the clear

2 Yurii Pivovarov, Andrei Fursov, “Russkaya Sistema i Reformy.” Pro et Contra 4 (1999): 178. 
shift to authoritarianism associated with Vladimir Putin's reign, there is an ample space for "plurality of contested identities,"3 and the idea of "Russia in plural" nicely grasps the diversity of discourses that both constitute and dislocate this country's identity. In an almost mythical manner, some authors think of Russia as a signifier for "what no adequate names can be imagined." On the one hand, even the cursory acquaintance with the Russian scholarly literature makes one believe in the possibility of endless scenarios for Russian foreign policy. Yet on the other hand, this seemingly unlimited number of options sometimes is artificially constrained by and locked in elementary dichotomies like "integration" vs. "isolation," "liberal reforms" vs. "conservative retreat," "going West" vs. "going East," etc. Piles of books trying hard to explain the intricacies of Russia's politics through the prism of concepts circulating exclusively within Russia - like the proverbial tug-of-war between "Westernizers" and "Slavophiles" - add little to the obvious deficiency in concepts capable of bridging the gaps of understanding between Russia and the West. Seemingly, both those believing that "everything is possible" and those restricting Russia's pathways to a limited number of oppositions are not only far remote from academic accuracy, but also counter-productive for scholarly research. Therefore, the question of how the plurality of Russian foreign policy discourses and the alternatives they entail may be inscribed into international scholarly literature remains in the forefront of academic interest.

In this section I will focus on two interrelated questions: how the spectrum of domestic ideas on Russia's foreign policy behaviour looks like, and what represents the international environment Russia contacts with and is part of. The second question in this list is arguably an ontological one, while the first one is mostly of epistemological background.

Plurality of Domestic Discourses. Firstly, the emphasis on a plurality of domestic conceptualizations could be instrumental in demonstrating the fragmentation of Russian political scene. Instead of focusing on the traditional distinction between Slavophiles and Westernizers, I see one of the most important split differently - between the technocratic and apolitical discourse of the Kremlin, on the one hand, and much more ideological and doctrinal discourses that originate in a wider public space, to include mass media and political parties, on the other.

3 Vincent Pouliot, “The Essence of Constructivism," Journal of International Relations and Development 7 (2004): 321.

4 Pertti Joenniemi, “Russia's Narrative Resources," Journal of International Relations and Development 11 (2008): 122.

5 Yurii Pivovarov, Andrei Fursov, Russkaya Sistema ..., p. 180. 
The official - hegemonic - discourse, to some extent, might be dubbed both post-political and apolitical, since it legitimizes itself through the references to something presented as either obvious ("neutral"/technical knowledge formulated in rational terms, i.e. with references to a presumably indisputable source of epistemic authority) or essential for national identity and integrity. ${ }^{6}$ What is hidden beneath this type of discourse is evidently power ambitions embedded in what seems to appear as presumably rational, objective and commonly shared arguments. The de-politicized discourse turned into an advocacy of reinforcing the state's roles in many policy spheres, both domestic and international. The limitations of individual freedoms under the pretext of security requirements, or the public legitimation of the Georgia war by the alleged humanitarian (human security-related) reasons appear to be less debatable than the same measures undertaken out of ideological or geopolitical motives.

As far as explicitly ideological discourses are concerned, as I have mentioned above, there is a century long Russian tradition of using for the purpose of selfdescription a flat axis usually constructed around two political poles drastically opposing each other. Most frequently they are dubbed "Slavophiles" and "Westernizers," though in other cases the names may differ - "Eurasianists" and "cosmopolites," "liberals" and "conservatives," "traditionalists" and "modernizers," "communists" and "democrats," etc. The differences between these dichotomous typologies boil down basically to the names of the poles and the hybrids that might be possibly placed somewhere in-between. Examples might include a number of tripartite schemes like: a) "liberal reformists," "national conservatives" and "moderate nationalist centrists," b) "liberal westernizers," "fundamentalist nationalists" and "pragmatic nationalists," c) "liberal westernism," "great power balancing" and "great power pragmatism"; d) "liberalism," "geopolitical realism," "pragmatic geoeconomics realism," "cultural geostrategic realism," 10 etc. Yet most of these typologies remain static, and thus oversimplify Russia's

6 Slavoj Zizek, The Ticklish Subject. The Absent Centre of Political Ontology (Verso: London \& New York, 2004), 131.

7 Tatyana Parkhalina, "Impacts of Domestic and Regional Factors on Russia’s Foreign and Security Policy," in Kurt Spillmann and Andreas Wenger, ed., Russia's Place in Europe. A Security Debate (Bern: Peter Lang Publishers, 1999), 48.

8 Margot Light, "Foreign Policy Thinking," in Malcolm N. et al., Internal Factors in Russian Foreign Policy (Oxford: Royal Institute of International Affairs and Oxford University Press, 1996).

9 Andrey Tsygankov, Russia's Foreign Policy: Change and Continuity in National Identity (Lanham: Rowman and Littlefield, 2006).

10 C.Thorun, Explaining Change in Russian Foreign Policy: The Role of Ideas in Post-Soviet Russia's Conduct towards the West (Basingstoke: Palgrave Macmillan, 2009). 
ideational landscape, reducing it to a number of "idea brokers" that seem to be self-organizing and capable of developing independently of each other and the wider international environment.

Besides, what the above mentioned 'flat' conceptualizations of Russia's ideational landscape leave unexplained is the driving forces that stay behind the presumed shifts from one policy platform - and a group that sustained it - to another. For example, what stipulated the transition from Andrei Kozyrev's proWestern diplomacy on the beginning of 1990s to the Evgenii Primakov model of multipolarity? One answer is presumably the force of reflexivity: following the example of Gorbachev's "new thinking" given by Alexander Wendt, one may assume that the change might be stimulated by the ability of power holders to analyze the policies they pursue and alter them as soon as they fail to properly work. Yet there is another explanation which points to the changes in Russia's external environment, like, for example, Russia's involvement in a number of violent conflicts that touched upon its identity (including Transnistria, South Ossetia, and Abkhazia) and thus predetermined the advent of a less 'naïve' and more 'pragmatic' foreign policy. The same goes for the transition from Yeltsin's to Putin's international strategy which may be explicated by a number of factors pertaining to the structure of international relations, including the events in Kosovo, Chechnya, Iraq, the double enlargement of NATO and EU, a series of colour revolutions, etc.

Thus, it is insufficient to demonstrate the plurality of domestic discourses and their interrelatedness. What has to be added to this analysis is the external institutional environment these domestic discourses appeal to. From here stems my second point, that one problematizing the "outer world" which Russia wishes either to integrate into or prevail in.

External Milieu. In the traditions of the English school, I will call this external environment "international society" (IS). "A society of states (or international society) exists when a group of states, conscious of certain common interests and common values, form a society in the sense that they conceive themselves to be bound by a common set of rules in their relations with one another, and share in the working of common institutions." ${ }^{11}$ The adjective "international" here denotes "anything involving interactions across or beyond the boundaries of sovereign states." 12 The noun "society" signifies that its members take each other

${ }^{11}$ Hedley Bull, The Anarchical Society. A Study of Order in World Politics (New York: Columbia University Press, 2002), 13.

12 Duncan Snidal and Alexander Wendt, "Why There Is International Theory Now," International Theory 1 (2009): 8. 
into account in choosing their actions. ${ }^{13}$ "English school theorists have focused on global civilizing processes that tame the ability to harm, whether for selfinterested reasons or because of the importance of international society," ${ }^{14}$ which explains why IS "is limited to those state actors, in conjunction with international institutions and non-state actors, who agree, more or less, on common interests and values." 15

There is one important point that underpins the need to approach the domestic and international discourses in close conjunction with each other. In the whole gamut of policy ideas flourishing within Russia one may find - and perhaps discard as dysfunctional - those neither presupposing nor envisaging any reasonably imaginable type of IS. Simply speaking, these ideas can't plug in either of international societies that can be reasonably envisaged or presumed. In particular, this is the case of the nativist doctrine of Russian slavophiles that refers to a mythical "pan-Slavic" identity shared, contrary to their expectations, by neither of the Slavic countries, even the closest to Russia, like Ukraine. Same is true about the doctrine of Eurasianism grounded in a dubious idea of specific Eurasian civilization of which Russia is supposed to be a "natural" leader.

\section{Inter-subjective and Structural Departures}

Methodologically, my approach is grounded in the assertion that "structures have prior causal power over agents. They provide the very conditions within which agents may act, defining and limiting this activity." ${ }^{16}$ An important point has to be made at this juncture. For some constructivist authors there is a difference between structural approach(es) and intersubjective one(s). It may be argued that "seeing a great power an intersubjectively constituted by the actors of a system is a very different thing from seeing it as structurally constituted by the states system." ${ }^{17}$ The difference was nicely grasped by Wendt: "structures of interaction may be called "micro"-structures because they depict the world from agents' point of view" 18 ; in the meantime, there are "macro"-structures that describe the

13 Alexander Wendt, Social Theory of International Politics (Cambridge: Cambridge University Press, 1999), 249.

${ }^{14}$ Andrew Linklater, "Grand Narratives and International Relations," Global Change, Peace and Security 21 (2009): 10.

15 Richard Beardsworth, "Cosmopolitanism and Realism: Toward a Theoretical Convergence?" Millennium: Journal of International Relations 37 (2008): 86.

16 Jonathan Joseph, "Hegemony and the Structure-agency Problem in International Relations: A Scientific Realist Contribution," Review of International Studies 34 (2008), 116.

17 Iver Neumann, "Russia as a Great Power, 1815-2007," Journal of International Relations and Development 11 (2008): 130.

18 Alexander Wendt, Social Theory of International Politics. 
world from the standpoint of the system. It appears that the macro-level is "more structural" and thus stable, while the micro-level is "more procedural" and thus constantly changing. ${ }^{19}$

The concept of intersubjectivity can be discussed as defining the nature of Russia's relations with Europe. In Wendt's vocabulary, these relations might be termed micro-structural because they are deployed within deeper structures of international society. It may appear that these relations are "destined for disconnection" and thrive on separation, "distancing, strangeness, and all the risks of miscomprehension." ${ }^{20}$ What these disconnections disclose is the interaction between two identity-based subject positions. In a narrow sense, the concept of inter-subjectivity points to the common areas where both parties communicate with each other as partners, and, concomitantly, not only the EU is capable of exerting influence upon Russia, as it used to be throughout 1990s, but Russia too may have some impact of its own. Inter-subjectivity presupposes that each type of influence has its reverse side, a sort of counter-influence. For example, Russia, being an object of EU-sponsored programs, exerted (perhaps unintentionally) some influence upon the EU in response - through either confirming or disproving the initial premises that framed the EU policies. A Russia which doesn't meet the EU expectations could be an argument in promoting a policy of stronger bordering and enhancing the "Self-Other" divide.

Yet in a wider sense inter-subjectivity signifies not only a possibility to achieve some practical effects and alter policies of other actors, but to constitute their identities. It is in this sense that I will employ the concept of inter-subjectivity in my analysis. ${ }^{21}$ In inter-subjective relationship, both parties constitute each other in a sense that the formation of Russian identity is impossible without references to European experiences and practices, and vice versa. Identities always relate to a 'constitutive other,'22 which was well grasped by Slavoj Zizek:

"When I reconstruct my life in a narrative, I always do it within a certain inter-subjective context, answering the Other's call-injunction, addressing the Other in a certain way... My very status as a subject depends on its links to

19 Petr Drulak, "The Problem of Structural Change in Alexander Wendt's Social Theory of International Politics," Journal of International Relations and Development 4 (2001), 370.

20 Jean Baudrillard, Marc Guillaume, Radical Alterity (Los Angeles: Semiotext(e), 2008), 31.

${ }^{21}$ It is important to note that, in author's judgment, not all relations are inter-subjective. For example, countries like Sri-Lanka and Uruguay do have certain (diplomatic and economic) relations but they are void of inter-subjective background since neither of these two countries defines its identity through the references to its counter-part.

22 Philipp Casula, "The Loss of the Constitutive Outside: Changing Discourses in East and West after the End of the Cold War" (Paper presented on Panel "Metaphors and Power" at the $6^{\text {th }}$ Pan-European Conference on International Relations, Turin, 15 September 2007). 
the substantial Other... (I)n the core of my being, I am irreducibly vulnerable, exposed to the Other(s)... (Yet - A.M.) confronted with the Other, I never can fully account for myself... I will never get from the Other a full answer to 'who you are' because the Other is a mystery also for him/herself... This mutual recognition of limitation thus opens up a space of sociality that is the solidarity of the vulnerable."23

Since Russia and EU constitute each other, their subject positions are immanently fluid, mobile and flexible. In the inter-subjective relations the two parties construct the subject positions of each other, which means that these positions are not pre-given. That is why it would be a gross oversimplification to treat inter-subjective relations as relations between two (or more) already given political subjects. The two subjects in/of communication, Russia and EU, are not only in the process of constant formation; what is more important is that both are internally dislocated, if by dislocation we understand indeterminacy, uncertainty, and undecidability. Russia can be portrayed as a political subject that proves incapable of speaking with a single voice internationally, one deeply fragmented by its desire to simultaneously use economic arguments (the case of sanctions against Poland, Georgia, or Moldova) and normative appeal (the case of lambasting Estonia for the removal of the Great Patriotic War monument in Tallinn in 2007). In the interpretation of its past, Russia is both a destructor of the Soviet empire (an argument constitutive for Russia's role as a co-sponsor of the Cold War termination) and a heritor of the USSR (an argument that explicates Russia's resistance to the Ukrainian and Polish memory politics grounded in remembrances about Golodomor and Katyn). In terms of Russia's present identity, it seems to be a mixture of a typically Realpolitik pragmatism (Medvedev argues that Western countries just have to accept the "reality" of secession of the two territories from Georgia and avoid emotional reaction to "virtual situations"24), on the one hand, and a liberal assumption that explains foreign policy by domestic developments (in Putin's interpretation, it is the presidential election in the U.S. that predetermines the position America took in this conflict $\left.{ }^{25}\right)$, on the other. Russian policies include both institutional commitments (Medvedev has vehemently called for a new European security architecture) and what might be called "reluctant unilateralism" (in Medvedev's assessment, Russia and NATO "may say good-bye to each other," but it is NATO that has stronger

${ }^{23}$ Slavoj Zizek, "Neighbors and Other Monsters: A Plea for Ethical Violence," in The Neighbor. Three Inquiries in Political Theology (Chicago and London: The University of Chicago Press, 2005),139.

${ }^{24}$ Dmitry Medvedev, Interview with Al Jazira TV, Sochi, August 26, 2008, http://www.kremlin. ru/text/appears/2008/08/205783.shtml

25 Vladimir Putin, Interview with CNN, August 28, 2008, http://www.government.ru 
interest in continuing the cooperation). Russian identity mixes up particularistic assumptions (each act of recognition is individual and singular, Medvedev says ${ }^{26}$ ) and universal explanations (by declaring that what Russia did in South Ossetia and Abkhazia "others have done in Kosovo,"27 Medvedev in fact accepted the logic of the "chain effect"). It appears that Moscow is eager to speak with many different voices simultaneously - for instance, insisting on the market-based relations with Belarus in the energy sphere, on the one hand, and acknowledging a special role of Belarus in hosting Russian military bases which are considered as an indispensable element of Russian security policy, on the other.

Yet there is also an external dimension of dislocation manifested by the dependence of subjects' identities "upon an outside which both denies that identity and provides its conditions of possibility at the same time." ${ }^{28}$ This is what dislocates Russia's identity as well: Russia is eager to get attuned to the dominating/winning discourse but reinstalls its subjectivity through the re-interpretation of its key discursive elements. The external dimension of dislocation appears to be crucial at this juncture. In this light, the EU may be perceived as a challenge to Russia, but nevertheless the Russian identity is constructed through some kind of communication with - and reference to - it. Indeed, each of the two parties inevitably refers to its counter-part in the process of constructing its identity, which testifies to the non-self-sufficient nature of these identities, and the unavoidable inter-penetrations and overlays.

In a wider sense, the dislocated character of Russia's and EU's identities can be approached through the concept of "the third agency to which we ... submit ourselves" ${ }^{29}$ in the communicative process. This alleged "third agency" is dubbed by Zizek an "impersonal symbolic Order," or "the multitude of empirical others" associated by rules, institutions and regulations. In other words, cont(r)acting with each other, both parties have to refer and appeal - in one way or another - to a wider set of international norms. Thus, one may argue, we need to move beyond the analysis "of inter-subjective practices to look at how these themselves are grounded in deeper structural relations... and understand inter-subjective relations $\ldots$ as rooted in deeper socio-cultural and economic conditions." ${ }^{30}$

26 Dmitry Medvedev, Interview with "Russia Today” TV station, Sochi, August 26, 2008, http:// www.kremlin.ru/text/appears/2008/08/205773.shtml

27 Dmitry Medvedev, Interview with BBC, Sochi, August 26, 2008, http://www.kremlin.ru/text/ appears $/ 2008 / 08 / 205775$. shtml

28 Aletta J.Norval, "Theorising Dislocations" (Paper presented at "New Stability, Democracy and Nationalism in Contemporary Russia" workshop, Basel, 26-27 th $^{\text {t }}$ September 2008), 3.

29 Slavoj Zizek, Neighbors and Other Monsters, 139.

30 Jonathan Joseph, "Hegemony and the Structure-agency Problem in International Relations: A Scientific Realist Contribution,” Review of International Studies 34 (2008), 128. 
Within the context of the analysis of the EU - Russia dialogue, the idea of the "third agency" can be introduced through the concept of the international society (IS).

The trajectories of the IS concept in Russia are far from easy. In political parlance, it is "international community" rather than "international society" which is evoked as a figure of speech whenever references to almost mythical upper-hand authority are needful for authorizing or legitimizing some claims as allegedly "universally" recognizable. In the meantime, some authors challenge the practicability of applying the concept of society to the sphere of international relations since they appear "phantoms," or "nicknames" for "real" agents like NATO, EU or USA. ${ }^{31}$ Others try to (mis)represent Bull's idea of the proliferation of international society as a liberal restatement of an old Marxist obsession with the expansion of "world-wide revolution." 32 Yet even most critical readings of Bull's concept does not preclude Russian IR scholars from admitting that the expansion of (world) IS is one of the key trends in the current international life; what is most frequently challenged is the political machinery that stays behind this trend, including the effects of bordering between the West and "underWest," 33 or what might be called a strategy of "crunching," or "plowing up" the geopolitical field for the sake of better assimilating the aspirants to joining the Western world. ${ }^{34}$

\section{International Society: a Meeting Point of the English School and Constructivism}

What is quite symptomatic is that the concept of IS could serve as a meeting point between, at least, two theoretical schools - the English school and social constructivism. On the one hand, "the English school and constructivism are linked by an emphasis on the power of ideas to affect change." 35 In fact, Wendt resorts to the concept of IS as an example of "social systems" or "social kinds" 36

31 Vladimir Maximenko, "Proiskhodit li globalizatsiya?" Pro et Contra 4 (1999): 88.

32 Alexei Bogaturov, "Globalizatsiya kak Sindrom Pogloschenia v Mezhdunarodnoi Politike," in Alexei Bogaturov, Nikolai Kosolapov, Mark Khrustaliov, Essays on Theory and Political Analysis of International Relations (Moscow: Academic \& Educational Forum on International Relations, 2002), 338.

33 Ibidem, 349.

34 Alexei Bogaturov, “Strategia Peremalyvania' vo Vneshnei Politike SShA,” in Alexei Bogaturov, Nikolai Kosolapov, Mark Khrustaliov, Essays on Theory and Political Analysis of International Relations (Moscow: Academic \& Educational Forum on International Relations, 2002), 364.

35 Balkan Devlen, Patrick James, Ozgur Ozdamar, “The English School, International Relations, and Progress," International Studies Review 7 (2005): 182.

36 Alexander Wendt, Social Theory of International Politics, 376. 
which give meaning to ideas held on the state level and, I would add, within the state as well. On the other hand, the concept of IS resonates well with the idea of the international which, in interpretation of R.B.J.Walker, connotes with a set of legitimate and widely accepted rules that modern political subjects adhere to. "The international" is characterized, in his view, by four denials: no single imperial form is allowable, no religious wars are tolerated, no 'barbarian' or 'nonmoderns' accepted as equals, and no specifically political instruments, including violence and coercion, can be applied in relations between political subjects. ${ }^{37}$

In the English school reasoning, IS seems to be a type of foundational argument, one based upon induction and logic. Foundational arguments can't be proven true or false, yet they are presented as indispensable conditions of knowledge. "Epistemological and ontological positions, portrayed as bedrock foundations about the structure of the world and our knowledge of it, are beyond refutation." ${ }^{38}$ Constructivists appear to share this methodological posture presuming, as Wendt does, that "taking something as given is necessary in any explanatory endeavour by virtue of the simple fact that it is humanly impossible to problematize everything at once." 39

Hedley Bull makes it quite explicit that IS is an idea in the first place, and that it is the distribution of ideas that shapes each specific type of IS. He repeatedly purports that initially the concept of IS was conceived by the natural-law thinkers, then "converged with historians." ${ }^{40}$ In the meantime it would be correct to portray IS a social construct as well, which of course does not question the ideational/intellectual background of the concept. The social nature of IS is due to the fact that its norms and principles are widely shared among international actors.

There are at least two important effects stemming from the recognition of the ideational nature of IS. Firstly, as Hedley Bull rightly assumes, there is a problem of establishing interlinks between the "ideas of philosophers, international lawyers and historians," "the thoughts of statesmen" and what he calls "the reality of international society."41 This triad, by and large, corresponds to my research design in two respects. On the one hand, I am interested in how theories (including that one of IS) are related to political doctrines that motivate

37 R.B.J. Walker, “Lines of Insecurity: International, Imperial, Exceptional," Security Dialogue 37 (2006): 67-71.

38 Nuno Monteiro and Keven Ruby, "IR and the False Promise of Philosophical Foundations," International Theory 1 (2009): 26.

39 Alexander Wendt, Social Theory of International Politics, 36.

40 Hedley Bull, The Anarchical Society, 31.

${ }^{41}$ Ibidem, 38. 
policy makers. On the other hand, I pay attention to a more theoretical question of how and whether a certain type of ideas might be fathomed against the so called reality, whatever one may understand by it.

Secondly, since the IS roots has to be looked for in the sphere of ideas, it would be quite logical to assume that at certain time there might be more than one type of IS. "Reality might not be working according to one logic, (and there is A.M.) the possibility of the existence of more than one truth simultaneously." ${ }^{2}$ Hence, there may be "simultaneously existing social realities where it might not be possible to claim that one is superior to the other," ${ }^{\prime 3}$ and the endless plurality of interpretations of reality is embodied in the different descriptions of the IS. Therefore, along with the "Russia in plural" argument another one has to be advanced, namely "IS in plural."

The admission of the co-existence of different models of IS challenges the two dominating understandings of the plurality of international societies as seen from either temporal or geographic perspectives. In other words, the differences between international societies are usually induced from either the temporal shift from one model to another (for example, from the "Christian" to "European" society), or as the grounding of international societies in a predetermined regional context (in this reading, one may speak of "European," "North American," "South East Asian" and other types of IS). Yet I will argue that the idea of plurality of international societies can be also understood as a competition of different - and alternative to each other - concepts of structural interconnections that are not necessarily bound by the logics of territoriality and temporality.

The multiplicity of international societies might serve as an explanatory argument for the corresponding multiplicity of Russian foreign policies. In many studies the story of Russian foreign policy since the demise of the USSR is told as a series of models that continuously either destroy or deny their predecessors. Yet what if these models, despite all controversies that divide them, may co-exist as different pathways, or vectors that constitute the menu of Russia's foreign policy choices? Thus, the seeming marginalization of the early liberal westernizers did not mean the effacement of the perspective of Russia's integration into the IS dominated by the Western norms; in the same vein, Russia's incorporation of the normative arguments in its foreign policy arsenal does not mean the ultimate refuse from the more traditional geopolitical approaches.

42 Katalin Sarvary, "Devaluing Diplomacy? A Critique of Alexander Wendt's Conception of Progress and Politics," Journal of International Relations and Development 4 (2001): 381.

43 Ibidem, 381. 
Different types of international society are, on the one hand, social constructs, and, on the other, real though invisible. They may serve to denote certain vectors, or perspectives of the dynamics of international relations. They are ideal types that are mixed together in practice. In the meantime, the different types of the IS may be used as independent variables, those applicable for explaining other phenomena, in other words - for emphasizing the causal powers of the structure of the international society in explaining not only state behaviour, as Wendt does, but also the mosaics of different discourses within the state. To paraphrase Wendt, these discourses - both theoretical and doctrinal are "differently structured by the system so as to produce different effects." ${ }^{44}$

Constructivist literature is most helpful in shedding light on the importance of macro-structural matters, as exemplified, in particular, in Pierre Bourdieu's "structuralist constructivism." Bourdieu believed that social structures are existent, yet they don't necessarily predetermine agents' actions - they rather develop what might be termed "collective habitus," or cultural predispositions which include "structuring rites" and constraints. Habitus can be compared with "mental maps," sets of beliefs and values, or "unspoken assumptions" on what is thinkable and unthinkable under a given structural environment. ${ }^{45}$

This point was captured by Wendt who argued that structures not only constrain but - what is more important - constructs agents. To adopt Wendt's theory for the purpose of my analysis, a number of caveats have to be made. Firstly, in this construction process the plurality of external - structural conditions forcefully diversifies the ideational landscapes thus making possible for multiple theories and doctrines to occupy their intellectual niches. Structural factors, in a way, select ideas, boosting some of them and marginalizing others. These ideas become "logically dependent on the specific external structure" the state is embedded in, and "do not exist apart from external conditions." 46 Structures, Wendt argues then, confront agents "as an objective social fact that constrains and enables action in systematic ways, and as such should generate distinct patterns" ${ }^{\prime 7}$ of role-taking and role-playing.

Secondly, what should be added to the Wendtian version of social constructivism is the approach to structures as "containers" of hegemonic relations. Hegemony can be conceptualized as an "institution of international

\footnotetext{
44 Alexander Wendt, Social Theory of International Politics, 12.

45 Peter Jackson, "Pierre Bourdieu, the 'Cultural Turn' and the Practice of International History," Review of International Studies 34 (2008): 164-167.

46 Alexander Wendt, Social Theory of International Politics, 84.

47 Ibidem, 184.
} 
society." ${ }^{48}$ In fact, each of "social formations" (including each of the types of IS) harbour - if not conceal - what might be dubbed "hegemonic projects." Each structure may be approached as hegemonic, and one of the tasks of the IR scholars is to uncover these relations of hegemony. As Jonathan Joseph rightly presumes, "hegemony acts as a crucial mediating moment in the relation between structure and agency." ${ }^{49}$ Hegemony thus "reaches down to the structural issue of the reproduction of the social formation and the various structural ensembles... Hegemony comes to represent the political moment in the structure-agency relation." ${ }^{50}$ What stems from this is the need to understand what kind of hegemony is embedded in each of the four types of the IS, and how Russia reacts to them.

Thirdly, the taxonomy of international societies allows us to see the changing meanings of some of the most important concepts we use in international relations analysis. I'll give only a few examples of these transformations in meanings. One of the concepts that may be differently interpreted, depending on what type of IS it is placed in, is marginality. Under the conditions of collective unipolarity marginal territories are doomed to be absorbed by the coalition of dominating powers. Thus, marginality is a quality that denotes geopolitical disadvantages and unfortunate submission to the leading centres of power. Yet under certain circumstances marginality may turn into a resource that non-central actors dispose and utilize for shaping their peculiar identities and influencing the seemingly more powerful neighbours. Thus, under a multipolar type of IS, margins may either find their niches and remain unaffected by the possible rivalry between the competing poles, or plug into the sphere of influence of one of them. Within the frameworks of what I call "normative integration" marginal regions may formulate their identities in normative terms, like the countries of the Community for Democratic Choice (led by Ukraine and Georgia after the 'colour revolutions') wished to do. Finally, the normative plurality situation will most likely turn some of marginal regions into bones of contention with competing interpretations of their identities. Besides, the practical implementation of the strategy of marginality might bring different effects in different types of the IS structures. The Northern Dimension-type of marginality, with Russia accepting some of the European norms of trans-border cooperation, better fits the logic of "normative integration," while the Eastern Dimension/Eastern Partnership-type has to be placed within the logic of

48 Ian Clark, “Bringing Hegemony Back In: The United States and International Order," International Affairs 85 (2009): 27.

49 Jonathan Joseph, Hegemony and the Structure-Agency, 114.

s0 Ibidem, 128. 
multipolarity which spells the diversity of various power centres, including those alternative to Russia.

Another example may be given by different understandings of the "New Europe" concept. Within the unipolar type of IS the "New Europe" is associated with a strategy of American dominance in Europe. In 2003 the U.S. Secretary of State Donald Rumsfeld has labelled France and Germany an "Old Europe," ascribing to them not only reluctance to support US-led military operations, but also an inclination to protectionism and reluctance to modify their economies to be competitive. Yet in the norm-based type of IS the New Europe is connoted with an area in which the institutionalized frameworks of sub-regionalism have emerged, displacing old East-West divides. In this context, the conception of New Europe is believed to be not any longer about sovereignty, military security, and borders. Thus, the "New Europe" concept is two-fold. On the one hand, it can be in tune with political realism and the Westphalia worldview, yet on the other hand, it is open to reinterpret the role of geographically marginal countries as increasingly important international subjects.

\section{Four Types of International Society}

My analysis is based upon two presumptions that may be instrumental in identifying the four possible types (models) of the international society. First, I draw a distinction between the thick version of the international society which is (at least) rule-based and (at most) value-driven, and the thin one which is formed when two or more states may exert some impact on one another ${ }^{51}$ on the basis of "great power management and its consequent derivate institution, balance of power," 52 yet without any meaningful normative commitments. This dichotomy roughly corresponds to the distinction between what might be alternatively dubbed "normative" and "decisionist" types of the IS. Second, two other patterns of the IS may compete with each other - a unitary (otherwise called solidarist) and pluralist ones. The unitary model (supported, by and large, by the EU) is based upon more or less homogenous rules of the game for all actors involved, while the pluralist one (to which Russia sympathizes) admits the multiplicity of political singularities potentially clashing with each other.

Based upon these two - mostly theoretical - dichotomies, an elementary matrix of four types of the international society could be charted. These types are conceptually derived from the IR schools of thought, and in more practical terms will be used to see what is Russia's role in each of them.

${ }_{51}$ Hedley Bull, The Anarchical Society, 9.

52 Pami Aalto, "Russia's Quest for International Society and the Prospects for Regional-Level International Societies," International Relations 21 (2007): 463. 


\begin{tabular}{|l|l|l|}
\hline & Unitary & Pluralist \\
\hline Decisionist/"thin" & 1: Unipolarity & 3: Multi-polarity \\
\hline Normative/"thick" & 2: Normative integration & 4: Normative plurality \\
\hline
\end{tabular}

In accordance with Bull's logic, one may assume that different types of IS may be explained by the predominance of one element over the others. ${ }^{53}$ All four types of IS are social and ideational constructs, and are always "entities in the making." ${ }^{54}$ Therefore, neither of the types of IS can be captured or appropriated by a specific policy group. The IS is not somebody's possession; thus, it would be erroneous to try to establish correlations between each of the IS models and the corresponding fractions within foreign policy elites. The four types of IS, as ideal social constructs, can't "belong" to somebody. Depending upon complex circumstances, one single policy actor may stick to one or another of these ideational constructs without claiming a kind of "copyright" to or monopoly on either of them.

What this table shows is that different Russian identities might be inscribed in each of these four types of IS. In the proposed scheme, IS1 basically reflects an America-dominated type of international society, while IS2 appears to be closer to a norm-centered type. Against this background, IS3 and IS4 leave more space for Russia's own international subjectivity, though it still remains unclear what kind of IS - the key concept of this theoretical approach - Russia would like to invest in. The most important question is whether Moscow feels itself more comfortable in a normative/ rule-based type of IS, or in a kind of Schmittian/ decisionist type with the predominance of the logic of sovereign exceptions? Or perhaps it aims at forming a sort of alternative (non-Western) IS to be based upon the Collective Security Treaty Organization, the Shanghai Cooperation Organization or, possibly, the BRICS group?

In practical terms, each type of IS entails a certain role identity and consequent policy strategy. In model 1 Russia may play the role of junior partner. More specifically, this model can be sub-divided into two patterns: Pax Americana and "collective unipolarity." Consequently, Russia's policies might be grounded in either imitating the U.S. unilateralism or in accommodation with the U.S.-centric institutional structure. Model 2 presupposes Russia's role identity as integral part of normatively integrated international society. Under this scenario, Russia voluntarily recognizes the hegemonic nature of the Western norms and values, and accepts democratic procedures as indispensable background for international

53 Hedley Bull, The Anarchical Society, 39.

54 Stefano Guzzini and Anna Leander, "A Social Theory for International Relations: An Appraisal of Alexander Wendt's Theoretical and Disciplinary Synthesis," Journal of International Relations and Development 4 (2001): 327. 
socialization. ${ }^{55}$ Model 3 envisages Russia's identity as one of the major poles of power in the world. In this case Russia seeks to pluralize the international political scene and avoid monopoly of one sole political subject. Within the framework of model 4 Russia's identity is based upon the resistance to the West-dominated order. Under this scenario, Russia seeks to re-signify and re-interpret the dominating norms, rather than promote its own normative agenda.

\section{Conclusion}

In this paper I have explained the menu of Russian international identities by the variety of the patterns of international society which co-exist and offer alternative policy strategies for Moscow. The unipolar model, quite popular among Russian political elites in the beginning of 1990s, is now rebuffed since it turned out almost impossible for Russia to become part of the Western institutions and thus join the dominating coalition of powers. Since mid-1990s Russia turned to the alternative policy strategy of challenging the hegemony of the West through strengthening its own potential for gradually transforming into an autonomous pole of rather regional than global scale; hence Moscow's preference for spheres of influence approach over balance of power type of thinking. The role of presumably self-sufficient pole is understood by the Kremlin in predominantly material terms as either "energy superpower" or military power; what evidently lacks in Russian strategy of adjusting to and taking advantage of the multipolar world is normative aspects of leadership, including soft power resources, which fleshes out the stark differences between Russia and the European Union, especially as seen from the vantage point of their respective neighbourhood policies. The same is true with regard to the scenario of normative plurality which Russia overtly sympathizes with yet unfortunately is capable of only playing a role of a challenger of the Western normative order bereft of its own normative agenda recognized by - and attractive to - other members of international society. Russia seems to understand the width of the normative gap which divides it from the West and fears not a military attack from NATO but rather marginalization within the wider Europe, especially in security domain. This explains the launch of a campaign to propose a new set of common rules in the Euro-Atlantic region epitomized by Dmitry Medvedev's blueprint for new security architecture. Yet again what drastically diminished the international appeal of such a proposal is the unwillingness of the West to legitimize Russia's role as an equal political and security actor, which testifies to the chronic lack of normative and soft power resources in the hands of Russian diplomacy.

55 Andrey Bystritskiy, “Gibel’ ili Kontsert,” Apologiya, no. 9 (2006): 15. 